\title{
Tree-Ring Chronology in American Prehistory
}

$\mathrm{A}^{\mathrm{N}}$ archæologicale reconnaissance in 1920 of the Chaco Canyon, New Mexico, on behalf of the National Geographic Society of Washington, D.C., was followed by the decision of that Society to assume responsibility for the exploration of the two prehistoric sites of Pueblo Benito and Pueblo del Arroyo. Of these, the former is the most famous and important of the prehistoric remains of the south-western United States, the ruined structure consisting of a thousand rooms of stone and adobe. Its size alone bears out the evidence of the numerous ruined pueblos immediately adjacent that this now arid area once supported a large and densely concentrated population.

The investigations of the National Geographic Society were under the field direction of Dr. Niel M. Judd. They were carried out by successive annual expeditions in the period 1921-27. In addition to the exploration of the two villages, which were the main objective, observations were made on more than forty other sites in this important archæological area. The purpose of the expedition was not merely the study of the distinctive culture of Bonitian civilization, but also to determine as closely as possible the conditions which had led to the remarkable concentration of population and efflorescence of culture at this point, and above all, the causes of the decay of this civilization before the advent of the Spaniard to the American continent.

An investigation, which began more or less as a sideline, eventually produced a result of farreaching importance for American archæology, of which the end is not yet in sight. This was the application of the tree-ring method of dating to the chronological problem of Pueblo Bonito and other related prehistoric remains of this region.

When the expedition of the National Geographic Society in the Chaco Canyon area came to an end in 1927, it was intended to issue a comprehensive account of the exploration as a whole ; but owing to a variety of circumstances this project has had to be abandoned. The results of the expedition and the reports of those who have co-operated in the work, therefore, will appear in a series of independent papers to be known collectively as the Pueblo Bonito Series. Of these, the first, by Dr. A. E. Douglass, on the dating of the ruins by the study of tree-rings shown in the timbers of the buildings, is now available.*

* National Geographic Society. Contributed Technical Papers, Pueblo Bonito Series, No. 1: Dating Pueblo Bonito and other Ruins of the South-West. By A. F. Douglass. Pp. 74. (Washington, D.C.: National Geographical Society; 1935.)
The Pueblo Bonito Expedition first made contact with Dr. Douglass in 1921, when samples of timbers obtained in the first year of the expedition were submitted to him for examination; but it was not until the following year that intensive application of the method was made to the chronological problem at this ruin. Dr. Douglass, when engaged in an attempt to correlate climatic conditions with the periodic recurrence of sunspot activity through the study of tree-ring growth in northern Arizona, had been invited, in 1918, by Dr. Clark Wissler, of the American Museum of Natural History, to attempt a determination by this method of the comparative ages of the ruins of Aztec and Pueblo Bonito. His attention was thus directed to the possibility of dating prehistoric remains by the study of beams of timber surviving in the numerous ruins of the south-west, which presumably had been subject to like climatic conditions, and of constructing from this evidence the beginnings of a time-scale. When the operations at Pueblo Bonito came to an end in 1927, the dating of the ruin had not been determined to his complete satisfaction, and the second beam expedition of 1928-the first expedition took place in 1923-was followed by a third expedition in 1929. By this expedition what had appeared a gap in the evidence was successfully eliminated.

The tree-ring method of dating elaborated by Dr. Douglass is sufficiently well known by now to obviate detailed description. The essential feature is the identification in borings or sections of timber of certain distinctive sequence groups of the ringgrowth of the tree due to the influence of an identical annual succession of variation in climatic conditions. Although some thousands of specimens have been examined, no sequence has been found to be exactly duplicated in the course of a period of more than twelve hundred years. By means of the overlap in ring growth in timber at different stages of age at given points in time, it has been possible to build up a time-scale, which proceeds from living trees to historic timbers, namely, beams from buildings of known date, and from historie to prehistoric. Dr. Douglass here figures a complete series of ring growths, which extends from 1929 right back to A.D. 698 . The woods which have been found best for the purpose of the investigation are the western yellow pine (Pinus ponderosa) and the Douglas fir (Pseudotsuga taxifolia), while the next best is the pinyon (Pinus edulis). 
This elaborated time-scale has been applied to determining the age of a large number of ruins which have furnished the material from which it has been built up; but perhaps of even greater interest for the archæologist than the dating of individual structures is the precision given to the cultural periods, of which the time relation had been determined previously by archæological methods. For example, the beautiful cream. coloured Hopi ware is seen to begin in the early part of the fourteenth century, the polychrome red pottery largely filled the thirteenth, red pottery was common in the twelfth, and black-on-white ware was characteristic of the tenth and eleventh centuries. In more general terms, of the succession of cultural periods into which archæologists have classified Pueblo civilization, Pueblo III, the golden age of south-western prehistory, took its early form in Chaco Canyon about A.D. 919, reached its local climax in the late eleventh century, and probably closed with the great drought which endured from 1276 until 1299. Pueblo IV began in the early thirteen hundreds. Dating, however, is complicated by the problem of centrifugal diffusion. Pueblo culture, it is thought, probably originated at a single centre, from which it spread outwards. It is not, therefore, everywhere contemporaneous.

So far as the dating of individual ruins is concerned, Pueblo Bonito is now shawn to be the oldest of the south-western ruins. Its building began in A.D. 919, and the major construction took place in the decade 1060-70, with a lesser activity twenty years later. The important site of Aztec, notwithstanding its size, was built in a period of twelve years 1110-21. The dates determined for the beginning of construction on forty-five sites range from A.D. 919 until 1417, except for two instances, dated at 1550 and 1770 respectively.

The investigation has thrown light on a number of collateral problems. For example, there is the question of the former existence in this area of considerable pine forests, which have now disappeared, and by their extinction, no doubt, contributed their share to the aridity of the area. Some specimens which have been examined were evidently dead wood at the time they were used, and the confused and almost indistinguishable rings at the end of their growth bear witness to the aridity which eaused their death. This formation has been paralleled from trees which have died recently.

The evidence of the grouping of sequences of poor growth is interpreted as pointing to a suc. cession of droughts, which recurred with extreme severity at intervals of about three hundred years. One of these droughts, the most severe, covered the closing years of the thirteenth century (1276-99); another appears from 1573 until 1593; and still another in 1890, with a period of maximum intensity from 1896 until 1904. Periods of drought earlier than these are also perceptible, which go back so far as A.D. 904 . The study of these cycles should prove of importance for the future of climatology. Archæologists will look forward with keenest anticipation to the extension of this technique to conditions which will throw light on the beginnings of Pueblo culture and its dating in relation to the culture of the Basket-makers.

\section{Obituary}

Mr. R. D. Oldham, F.R.S.

$\mathrm{R}^{1}$ ICHARD DIXON OLDHAM, whose death took place at Llandrindod Wells on July 15, was an original and independent thinker-a little too independent sometimes for those in authority. He was most widely known for his geological work in India and his seismological investigations; but he wrote on other subjects, and his writings are always interesting and suggestive. He was the third son of Dr. Thomas Oldham, F.R.S., the first director of the Geological Survey of India, and was born on July 31,1858 . He was educated at Rugby and the Royal School of Mines, and appears to have been elected to a science scholarship at Emmanuel College, Cambridge, but never took it up. His father, who had retired two years earlier, died in 1878; and he, following his father's footsteps, accepted an appointment on the Indian Geological Survey in 1879.
In the regular fieldwork of the Survey, Oldham had a wide and varied experience, chiefly in the north, ranging from Manipur to Baluchistan; and he also visited the Andaman Islands. The results are to be found in many papers in the "Memoirs" and "Records" of the Survey. In addition to his fieldwork, he edited his father's unpublished papers on earthquakes and thermal springs in India. The most important of these dealt with the Cachar earthquake of 1869 , and the editing included the whole of the discussion of the observations collected by his father, a very useful grounding for his later work in seismology. He also compiled a "Bibliography of Indian Geology" (1888), and prepared the second edition of the official "Manual of the Geology of India" (1893). This was essentially a new work, though it incorporated much of the original edition; and several of the new chapters written by Oldham are of great 